\title{
Role of sea urchin Lytechinus variegatus grazing in regulating subtropical turtlegrass Thalassia testudinum meadows in the Florida Keys (USA)
}

\author{
John F. Valentine*, Kenneth L. Heck Jr, Kevin D. Kirsch, David Webb \\ Dauphin Island Sea Lab, 101 Bienville Blvd, Dauphin Island, Alabama 36528-0369, USA and \\ Department of Marine Science,University of South Alabama, Mobile, Alabama 36688-0002, USA
}

\begin{abstract}
In previous work, in St. Joseph Bay, Florida $\left(30^{\circ} \mathrm{N}, 85.5^{\circ} \mathrm{W}\right)$, in the northeastern Gulf of Mexico, we found that sea urchin Lytechinus variegatus grazing usually controlled seasonal changes in turtlegrass Thalassia testudinum abundance. In this study, we tested the generality of those conclusions by conducting new grazing studies in 2 turtlegrass habitats in the subtropical Florida Keys (USA). In the first experiment, we varied the duration of sea urchin grazing bouts in order to understand the impacts of temporally varying herbivory on seasonal changes in turtlegrass biomass in shallow water $(<2 \mathrm{~m})$ near Big Pine Key $\left(\sim 25^{\circ} \mathrm{N}, 85^{\circ} \mathrm{W}\right)$. In the second experiment, we examined the effects of chronic low levels of grazing on seagrass growth and biomass in a deeper-water seagrass habitat $(6$ to $7 \mathrm{~m})$ in Hawk Channel $\left(\sim 25^{\circ} \mathrm{N}, 80^{\circ} \mathrm{W}\right)$. These new studies suggest that the impacts of sea urchin grazing are highly variable in the Florida Keys. Depending on the season, urchin grazing lat densities of 20 ind $\mathrm{m}^{-2}$ ) had both negative and positive effects on seagrass biomass in Big Pine Key. If grazing occurred during spring, turtlegrass biomass was significantly reduced by short bouts of sea urchin herbivory. The impacts of this spring grazing extended into early summer. If grazing occurred in summer, sea urchins reduced turtlegrass biomass for only short periods of time, after which urchin grazing stimulated turtlegrass production. These findings are similar to those of previous grazing experiments conducted in St. Joseph Bay. In contrast, we found little evidence that ambient $(0$ to 8 ind. $\mathrm{m}^{2}$ ) densities of sea urchins could control either seagrass production or biomass in the deeper waters of Hawk Channel. The differences we found in grazer impacts on turtlegrass growth and abundance, in a well-lit shallow water habitat and deeper-water habitat with less light, suggest that there is a critical need not only to repeat experiments in environments with differing physical conditions but also to develop a more complete understanding of the mechanisms by which seagrasses can compensate for losses of tissues to marine herbivores under varying environmental conditions.
\end{abstract}

KEY WORDS: Seagrass · Herbivory · Sea urchins · Food webs

\section{INTRODUCTION}

Herbivores often determine the productivity and abundance of plants in aquatic environments (e.g., Porter 1973, 1977, Lynch \& Shapiro 1981, Lewis 1985, Vanni 1987a, Mallin \& Paerl 1994). For example, in freshwater lakes, zooplankton grazing can reduce the

\footnotetext{
•E-mail: jvalenti@jaguar1.usouthal.edu
}

abundance of small or naked phytoplankton species, favoring the survival of larger phytoplankton species with gelatinous sheaths or other structures that reduce their vulnerability to grazing (e.g., Porter 1973, 1977 , McCauley \& Briand 1979, Demot \& Kerfoot 1982, Vanni 1987b). In marine environments, grazing by coral reef fishes and invertebrates can cause dramatic shifts in macroalgal community structure from dominance by highly competitive, fast-growing, edible algae to competitively inferior, slower growing, but 
chemically defended algae (reviewed by Hay \& Steinberg 1992). Similarly, gastropod grazing can alter macroalgal community structure in temperate rocky intertidal zones by consuming competitively dominant, fast-growing, more palatable species, which are then replaced by competitively inferior, slower growing, less palatable species (reviewed by Lubchenco \& Gaines 1981, Gaines \& Lubchenco 1982). In perhaps the most dramatic example of herbivore impacts on marine plants, sea urchin grazing can convert macroalgal kelp forests to grazer-resistant coralline-dominated algal pavements in temperate and boreal settings (reviewed by Lawrence 1975). These observations suggest that herbivores can, at times, play an important role in determining both the composition of ecological communities and the manner in which energy flows from plants to higher order consumers.

In contrast to these better-studied habitats, grazing rates in seagrass meadows are believed to be very low. In part, this is because seagrasses are thought to contain little nutritional value, owing to the high $\mathrm{C} / \mathrm{N}$ ratios of their leaves (e.g., Bjorndal 1980, Duarte 1990) and the apparent inability of most invertebrate grazers to digest cellulose (Lawrence 1975). Current levels of seagrass herbivory are also thought to be low because of the low densities of larger vertebrate herbivores (e.g., green turtles, dugongs, manatees, fishes, and waterfowl) (Randall 1965, Heinsohn \& Birch 1972, Lipkin 1975, Charman 1979, Bjorndal 1980, Kiorbøe 1980, Jacobs et al. 1981, Thayer et al. 1984). In some areas, the proportion of seagrass production directly entering food webs via grazing is quite low (less than $15 \%$ of annual net aboveground primary production (NAPP) (Nienhuis \& Van Ierland 1978, Nienhuis \& Groenendijk 1986, Cebrián et al. 1996, Cebrián \& Duarte 1998). Most seagrass production is believed to enter coastal food webs through the detrital pathway (e.g., Fenchel 1970, 1977, Kikuchi \& Pérès 1977, Kikuchi 1980, Nienhuis \& Van Ierland 1978, Thayer et al. 1984, Nienhuis \& Groenendijk 1986, Zieman \& Zieman 1989).

There is evidence, however, that the underlying assumptions of this grazing paradigm need reevaluation (Klumpp et al. 1993, Cebrián \& Duarte 1998, Valentine \& Heck 1999). For example, investigators have shown that the nitrogen concentration of the leaves of many seagrasses, often considered to be an indicator of plant nutritional quality, is similar to that of algal tissue (Lowe \& Lawrence 1976, Lobel \& Ogden 1981; reviewed in Thayer et al. 1984). There is substantial evidence that detrital seagrass, the predominant pathway for the flow of energy from seagrasses to higher order consumers, is an even poorer source of nutrition (i.e., has lower leaf nitrogen content) for consumers than are living leaves (Harrison \& Mann 1975,
Zieman 1975, Fenchel 1977, Thayer et al. 1977, Rice 1982, Klumpp \& van der Walk 1984]. The use of C/N ratios to assess the nutritional value of seagrasses to herbivores can be traced to Russell-Hunter (1970), who concluded that food with a $\mathrm{C} / \mathrm{N}$ ratio $<17$ was required to satisfy human protein requirements. Surprisingly, the relevance of this frequently used ratio as an indicator of the low nutritional quality of seagrass leaves has never been verified with marine herbivores (cf. Thayer et al. 1977, Hatcher 1994). It has been suggested, however, that the $\mathrm{C} / \mathrm{N}$ ratio in seagrass leaves may actually be poor descriptors of their nutritional quality (Harrison \& Mann 1975, Klumpp et al. 1989, Hatcher 1994). Therefore, based on available data, it seems premature to conclude that the nutritional content of seagrass leaves, by itself, limits the rate at which seagrasses are grazed (cf. Cebrián \& Duarte 1998).

In St. Joseph Bay, Florida, we found that the sea urchin Lytechinus variegatus, at densities of 10 to 40 ind. $\mathrm{m}^{-2}$, could have important impacts on turtlegrass Thalassia testudinum abundance during the fall, winter, and spring (Valentine \& Heck 1991). However, once grazing pressure was relaxed, seagrass biomass rapidly reached levels that exceeded those measured in nearby ungrazed seagrass habitats (Valentine \& Heck 1991). During summer, we found little evidence of grazing impacts on seagrass abundance, even at very high urchin densities. We also found that persistent grazing in plots where rhizomes were severed at the borders of the plots, thus preventing the allochthonous input of belowground reserves, could create persistent barren unvegetated substrates in short periods of time, especially during the winter and spring (Heck \& Valentine 1995). From this, we concluded that belowground reserves allow turtlegrass to persist where herbivory is intense and can, depending on the season, allow seagrasses to recover rapidly to levels that equal or exceed nearby ungrazed plots (Valentine \& Heck 1991, Valentine et al. 1997). During summer months we found that grazing triggered an increase in areal NAPP (Valentine et al. 1997). These results suggested to us that seagrasses have as yet undescribed abilities to compensate for losses of leaf tissue to herbivores, the existence of which could lead to a significant underestimate of the amount of seagrass material consumed by herbivores (Valentine \& Heck 1999).

Through this study, we evaluate the generality of our previous work in the northeastern Gulf of Mexico by describing the findings of 2 additional experiments done in the Florida Keys. These experiments were designed to (1) assess the impact of varying intensities of sea urchin grazing on turtlegrass abundance and (2) the ability of turtlegrass to compensate for losses to grazers in both shallow $(<2 \mathrm{~m})$ and deeper-water $(6$ to $7 \mathrm{~m}$ ) sites. 


\section{METHODS AND APPROACH}

Description of study sites. The 2 study sites were located in the Florida Keys-one in the northern Keys (Hawk Channel) the other in the middle Keys (Big Pine Key) (Fig. 1). The depths at the Big Pine Key and Hawk Channel study sites were approximately 1.5 and $7 \mathrm{~m}$, respectively. As such, these sites are representative of the range of depths at which turtlegrass is commonly found in much of south Florida (Zieman \& Zieman 1989). Water temperatures vary seasonally, ranging from $14^{\circ} \mathrm{C}$ in winter to $35^{\circ} \mathrm{C}$ in summer in this region (Roessler \& Tabb 1974).

The seagrass habitats of south Florida are dominated by monospecific stands of turtlegrass Thalassia testudinum, but shoalgrass Halodule wrightii and manatee grass Syringodium filiforme are also present (Roessler \& Tabb 1974, Roessler et al. 1975, Thorhaug \& Roessler 1977. Kenworthy \& Schwarzchild 1998). As in north Florida, turtlegrass production is seasonal in south Florida but the growing season is longer, extending over some 7 to 8 mo (Zieman 1975, Thorhaug \& Roessler 1977). South Florida standing crops of turtlegrass peak at $1800 \mathrm{~g}$ dry wt $\mathrm{m}^{-2}$, while leaf densities have been reported as high as $5800 \mathrm{~m}^{-2}$ (Zieman 1975).

The grazing experiments. Big Pine Key: Two experiments were designed to (1) assess the impacts of varying intensities of episodic sea urchin grazing on turtlegrass abundance in a seasonally productive shallow water seagrass meadow and (2) determine the rate at which turtlegrass biomass recovers following the relaxation of grazing pressure. Experiments were conducted in 2 seasons, spring (February through May) and summer (June through August), to assess the range of seagrass responses to herbivory to changing seagrass productivity. The cages used in the spring grazing experiment were sustained through July in order to assess the potential for sea urchins to create barren unvegetated substrates, as we found in St. Joseph Bay. Grazing experiments were conducted using 12 replicate $5 \mathrm{~m}^{2}$ cages which were randomly assigned to a $2 \times 6$ array haphazardly located in an undisturbed turtlegrass meadow along the northern edge of Big Pine Key. Cages were constructed with $30 \mathrm{~mm}$ plastic mesh that was attached to rebar stakes. Experimental treatments consisted of an ungrazed control and 3 grazing treatments of varying duration. In the first grazing treatment, sea urchin density was held constant at 20 sea urchins $\mathrm{m}^{-2}$ for $1 \mathrm{mo}$, after which time the sea urchins were removed. In the second grazing treatment, this same sea urchin density was sustained for $2 \mathrm{mo}$, and then sea urchins were removed. In the third treatment, sea urchin density was held constant for 3 mo and then sea urchins were removed. The duration of the grazing treatments and sea urchin densities used in these experiments were based on the temporal range of reported patterns of sea
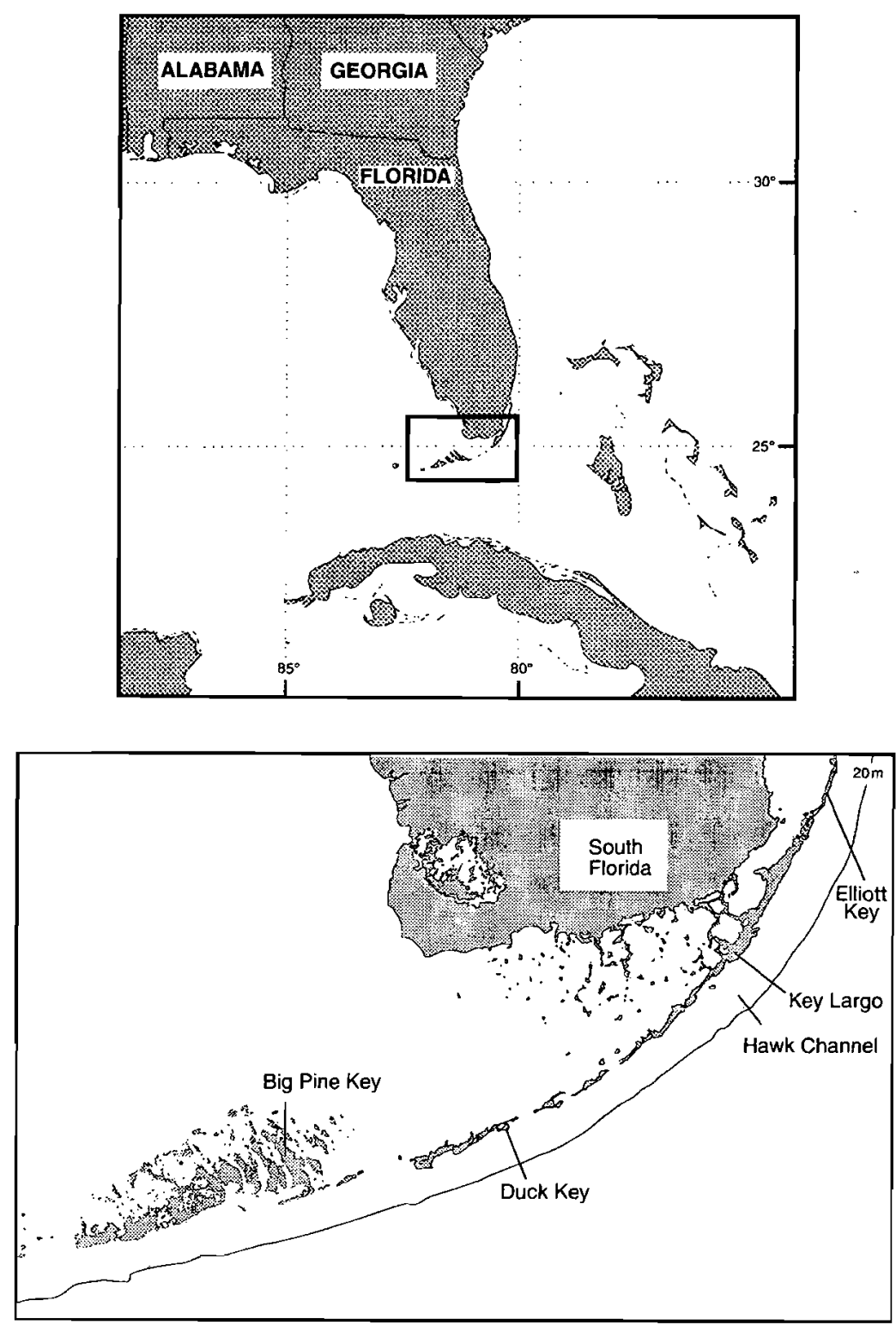

Fig. 1. Locations of the study sites in the Florida Keys (USA] 
urchin grazing (Camp et al. 1973, Greenway 1976, Bach 1979, Engstrom 1982, Valentine \& Heck 1991, Rose et al. 2000). The density of 20 ind. $\mathrm{m}^{-2}$ used in this experiment was chosen because it was the median density used in our previous experiments in St. Joseph Bay (Valentine \& Heck 1991). Following the relaxation of grazing pressure, we maintained the integrity of the cages in an effort to determine the rate of seagrass recovery following the cessation of grazing. Each treatment was replicated 3 times.

The impact of sea urchin grazing was monitored by collecting 3 haphazardly located, $0.01 \mathrm{~m}^{2}$ clippings of aboveground biomass from each cage, and 3 core samples ( $5 \mathrm{~cm}$ diameter $\times 15 \mathrm{~cm}$ deep) of belowground turtlegrass biomass from each cage at 3 to 4 wk intervals. Core samples were collected from the same location as the aboveground biomass clippings. Sampling locations were marked with labeled wire stakes to ensure that no area was sampled more than once. The total amount of area sampled from each replicate cage was calculated to be $0.6 \% \mathrm{mo}^{-1}$. Samples were frozen and returned to the laboratory for analysis.

In the laboratory, aboveground biomass ( $g$ dry wt), was measured by drying clipped leaves in an oven at $60^{\circ} \mathrm{C}$ following the removal of leaf epiphytes by scraping with a razor blade. Leaves were dried to a constant weight. Core samples were washed over a $500 \mu \mathrm{m}$ sieve to separate plant biomass from all sediments. Plant material was placed in pans and separated from infaunal organisms, dried to a constant weight, at $60^{\circ} \mathrm{C}$, and weighed $( \pm 0.01 \mathrm{~g})$.

Hawk Channel: Twenty-one $1 \mathrm{~m}^{2}$ cages constructed with $30 \mathrm{~mm}$ mesh plastic aquaculture netting and iron rebar were placed in a continuous turtlegrass habitat during the onset of the seagrass growing season. Sea urchins placed in these enclosures ranged in size from 45 to $55 \mathrm{~cm}$ horizontal diameter. Grazing intensity was manipulated in 3 treatments of 0,4 , and 8 ind. $\mathrm{m}^{-2}$. These densities were based on the range of average densities found in Hawk Channel in an initial survey of the study area ( $n=49$ ). Each treatment was randomly assigned to 7 of 21 cages.

Sea urchins were enclosed in cages from May through July, after which time they were removed for $1 \mathrm{wk}$. During this interruption of grazing, several estimates of turtlegrass abundance, growth and biomass were made. The grazing impact on areal NAPP was measured (using a modified hole punch technique; Kirkman \& Reid 1979) by marking all turtlegrass shoots within 3 haphazardly placed $0.01 \mathrm{~m}^{2}$ quadrats in each cage. Leaves in each shoot were marked by punching holes through all leaves at the top of each shoot sheath. After $6 \mathrm{~d}$, all of the marked shoots were clipped where the shoot attaches to the rhizome. Harvested shoots were frozen and returned to the laboratory for analy- ses. Sea urchins were restocked following the harvesting of the marked shoots. From these samples, we recorded shoot density, aboveground seagrass biomass, and leaf epibiont biomass.

We also documented changes in belowground biomass. Belowground plant material was collected from three $15.24 \mathrm{~cm}$ diameter cores pushed $15 \mathrm{~cm}$ into the sediment. These core depths are within the turtlegrass rhizosphere (Williams 1990). Extruded cores were placed in a $500 \mu \mathrm{m}$ sieve to separate the belowground plant material from the sediment. Belowground plant material was frozen and returned to the laboratory for analysis.

In the laboratory, areal NAPP ( $g$ ash free dry wt [AFDW] $\mathrm{m}^{-2} \mathrm{~d}^{-1}$ ), aboveground seagrass biomass (g AFDW m ${ }^{-2}$ ), shoot-specific growth (g AFDW shoot ${ }^{-1}$ $\mathrm{d}^{-1}$ ), shoot density (no. $\mathrm{m}^{-2}$ ), and epibiont biomass (g AFDW $\mathrm{m}^{-2}$ ) were determined from each sample. Areal NAPP was defined as the mass of all blade tissue between the initial puncture scar and the top of the shoot sheath, plus any new unmarked blades formed during the $6 \mathrm{~d}$ period. Aboveground seagrass biomass was calculated as the sum of all blade tissue collected in each quadrat. All growth and biomass samples were dried to a constant weight at $60^{\circ} \mathrm{C}$. After dried samples were weighed ( $\pm 0.1 \mathrm{mg}$ ), they were ashed in a muffle furnace at $500^{\circ} \mathrm{C}$ for $5 \mathrm{~h}$. Ashed samples were placed in dessicators to cool and then reweighed $( \pm 0.1 \mathrm{mg})$. Epibiont mass was measured by scraping attached animals and plants from each side of each leaf with a razor blade then drying and weighing epibionts as described above $( \pm 0.01 \mathrm{mg})$. We measured epibiont biomass because these organisms can shade seagrass blades and potentially alter NAPP.

Surveys of sea urchin density in the northern and middle Florida Keys: To assess the distribution and density of Lytechinus variegatus at our study sites in the northern and middle Florida Keys, we conducted 3 separate surveys. In one, we recorded the densities of this sea urchin at stations located at $4.8 \mathrm{~km}$ intervals along the center of Hawk Channel from $2.5 \mathrm{n}$ miles ESE of Elliott Key southwest to just offshore of Duck Key. At each station, we recorded sea urchin densities from three $1 \mathrm{~m}^{2}$ quadrats haphazardly dropped within a turtlegrass meadow. The total length of this survey covered some $80 \mathrm{~km}$. In the second survey, we documented changes in sea urchin densities at our study site in Hawk Channel over a 17 mo period by haphazardly dropping a $1 \mathrm{~m}^{2}$ quadrat $(\mathrm{n}=10)$ and counting all sea urchins within the quadrat during each visit. In the third survey, at Big Pine Key, we recorded sea urchin densities from 21 haphazardly located $1 \mathrm{~m}^{2}$ quadrats at 3 locations around the island.

Statistical analyses. The Big Pine Key experiment: To determine the impacts of sea urchin grazing on sea- 
sonal changes in seagrass abundance, growth and biomass we used a repeated measures analysis of variance (RMANOVA). Before conducting RMANOVA, Levene's test of equality was used to inspect data for homogeneity of variance on each sample date. In some cases, the data violated this assumption. These violations did not lead to increased incidence of Type I error (rejecting a true null hypothesis), as in none of these cases did we find evidence of significant grazing effects on seagrass abundance, growth, or biomass.

RMANOVA analyzes repetitively sampled replicates using both univariate and multivariate approaches. Output is in the form of between-subject effects and within-subject effects. Each examines data from a different perspective.

Between-subject effects represent a test of the overall significance of the experiment and treatment effects averaged over time. Computationally, the univariate and multivariate analyses of between-subject effects are the same. When significant between-subject differences were detected, a posteriori comparisons were made using the least significant difference test.

Within-subject effects comparisons represent a test of how treatments affect changes in a variable over time. For within-subject effects, the univariate approach is more powerful than the multivariate approach but has more restrictive assumptions (i.e., the circularity of the variance covariance matrix) (von Ende 1993). To test if the data met this assumption, we used Mauchly's test of sphericity. When sphericity is violated the $F$ statistic can be inflated, thus increasing the probability of making a Type I error. When the sphericity assumption was violated, we made a Huynh-Feldt adjustment by multiplying the numerator and denominator degrees of freedom by epsilon ( $\varepsilon$ ) (von Ende 1993), and $F$ values and probabilities were recalculated (von Ende 1993). Once the probabilities were recalculated, results were inspected for significant within-subject treatment effects. When data were adjusted in this way, we also used the output of the RMANOVA multivariate testing of within-subject effects to interpret the data. While the MANOVA approach does not require that the matrix be circular, it does assume that the variancecovariance matrices across cells are the same. To test this assumption we used a Box M test. In some cases, we were unable to conduct the Box $M$ test and multivariate output was not used. In those cases, our interpretation of within-subject effect data is based on the results of the univariate test. In addition, we calculated the statistical power of each comparison, at the $5 \%$ level of significance, as an indication of the strength of the $F$ test for each main effect. In this case power is the probability that our $F$ test will detect the difference between groups equal to those implied by the sample differences.
The Hawk Channel experiment: Initially, we intended to conduct this experiment from May until the end of September. Sampling was to take place in May, July and September. However, the passage of a tropical low that generated gale force winds for over $11 \mathrm{~d}$ in September breached 7 of our cages and allowed sea urchins to escape. The week before the storm, divers had checked the cages and found them intact. Consequently, we limit our analyses of the experiment to 2 sets of data. The first collected in May, prior to the inclusion of sea urchins in our grazing treatments. The second, collected in July, was the last month that we sampled.

One-way ANOVA was used to separately analyze samples collected in each month. Shoot density was transformed using a square root transformation to ensure that the variances were independent of the means. Other measured parameters satisfied the assumptions of ANOVA and were not transformed. Results were considered highly significant at the 5\% level of significance and marginally significant at the $10 \%$ level of significance. All statistical analyses were conducted using the SPSS ${ }^{\mathrm{TM}}$ statistical package for personal computers.

\section{RESULTS}

\section{Grazing in Big Pine Key}

Sea urchin grazing, regardless of duration, significantly affected turtlegrass biomass (both above- and belowground) in each of our experiments (Tables 1 to 4, both between-subject effects and within-subject effects: time $\times$ treatment interactions). The manner in which sea urchin grazing affected biomass varied between seasons, indicating a need to account for seasonal variation in seagrass growth when studying seagrass herbivory (Tables 1 to 4, within-subject effects: time $\times$ treatment interactions].

Grazing had a highly significant effect on turtlegrass aboveground biomass in the spring experiment (Fig. 2a, Table 1, between-subject effects). The marginally significant interaction between time and grazing (Table 1, within-subject effects: time $\times$ treatment interaction [univariate only]) indicates that treatment also had a weak effect on the rate at which aboveground biomass changed during this experiment (Fig. 2a).

A posteriori contrasts of the grazing treatments (between-subject effects) showed that the impacts of grazing on aboveground turtlegrass biomass were not uniform. For example, in the first month of the experiment, when sea urchins were present in all of the grazing treatments, aboveground biomass decreased faster in the 

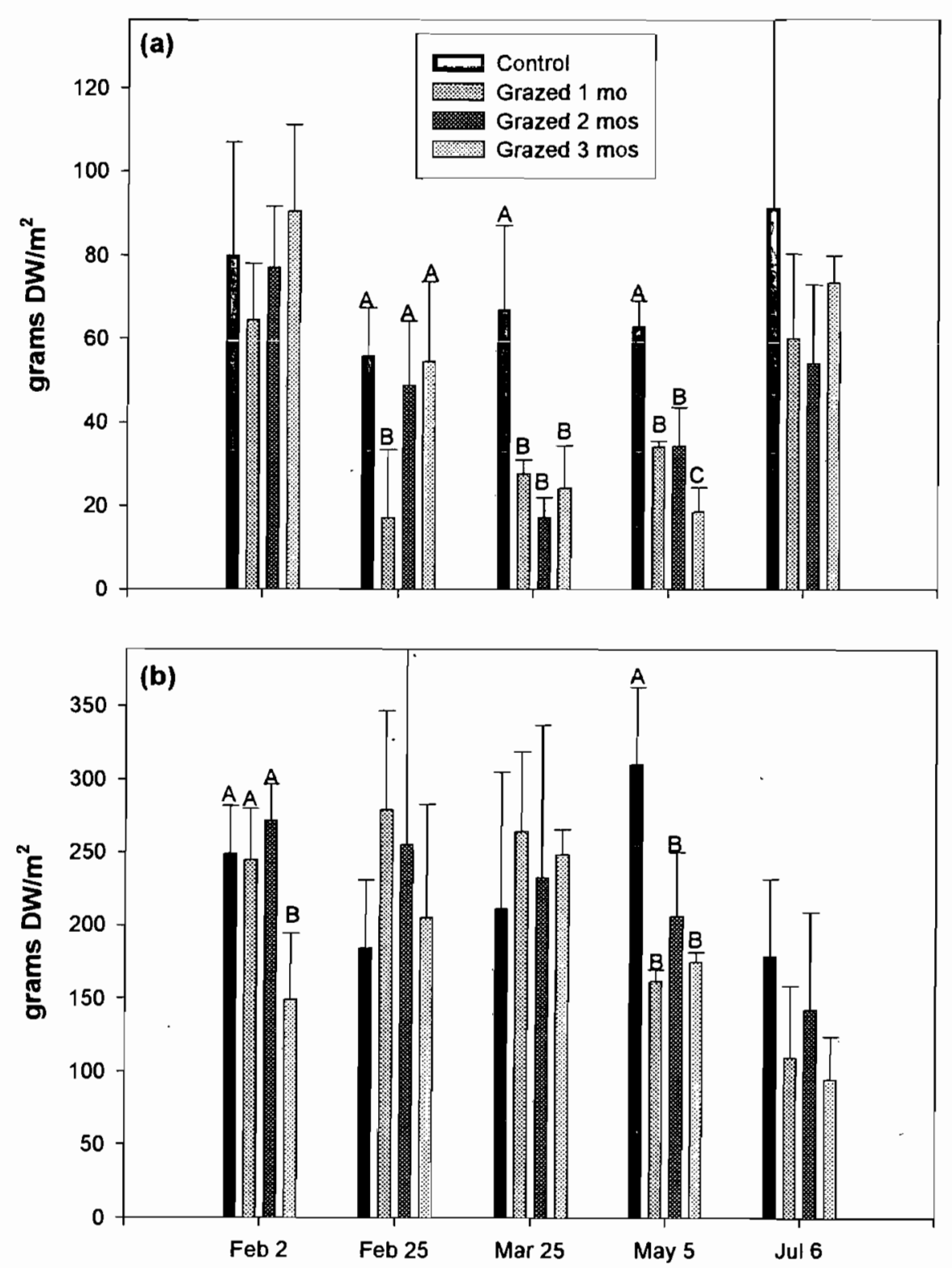

Fig. 2. [a) Aboveground and (b] belowground biomass in cages grazed by sea urchins for either 1, 2 or 3 mo during spring in Big Pine Key (mean $+1 \mathrm{SE}, \mathrm{n}=3$ ). Letters indicate treatments that were significantly different

grazing treatments than in the ungrazed control treatment (Fig. 2a). Despite this, only 1 grazing treatment had significantly lower aboveground biomass (i.e., the treatment grazed for only $1 \mathrm{mo}$ ) than the control (ungrazed) treatment. In the second month of the experiment, a posteriori comparisons found that all grazing treatments, even the treatment where grazing pressure was released a month earlier, had significantly less biomass than the control treatment. These significant differences persisted until the end of the experiment, when significant differences among the treatments no longer existed. A marginally significant interaction between the grazing treat- ments and time shows that grazing also had a small effect on changes in belowground biomass during spring (Table 2, within-subject effects). The manner of this interaction is unclear, as there were no consistent increases or decreases in belowground biomass among treatments. Pairwise contrasts on successive sampling dates show that the interaction became significant in May, when all of the grazing treatments had significantly less belowground biomass than the ungrazed control treatment (Fig. 2b).

Sea urchin grazing also had a significant impact on aboveground turtlegrass biomass in summer, although 
Table 1. Repeated measures ANOVA of spring grazing effects by Lytechinus variegatus on aboveground biomass in Big Pine Key, Florida. Bold indicates statistically significant differences among treatments. Differences were considered to be highly significant when $p<0.05$ and marginally significant when $p<0.10$. Note: data do show homogeneity of treatment variances (Sphericity test, $\mathrm{p}=0.065 ; \mathrm{df}=2$ ). Box $\mathrm{M}$ test could not be computed because there were fewer than 2 nonsingular cell covariance matrices

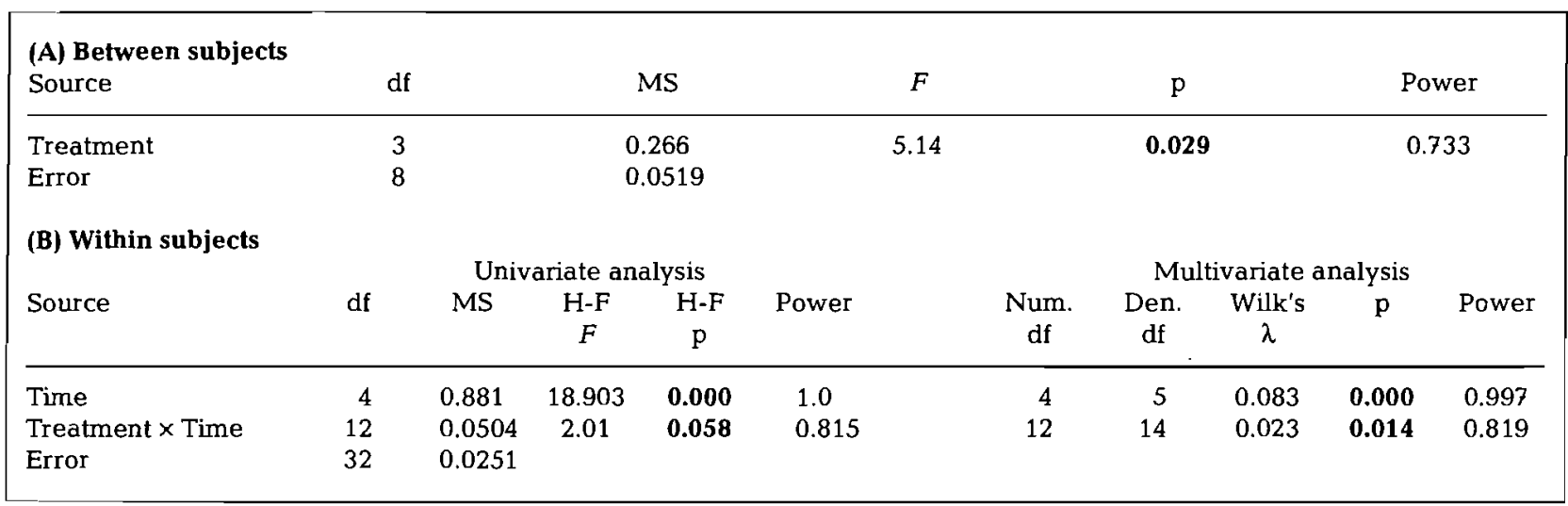

Table 2. Repeated measures ANOVA of spring grazing effects by Lytechinus variegatus on belowground biomass in Big Pine Key, Florida. Bold indicates statistically significant differences among treatments. Differences were considered to be highly significant when $p<0.05$ and marginally significant when $p<0.10$. Note: data do show homogeneity of treatment variances (Sphericity test, $\mathrm{p}=0.053_{\mathrm{i}} \mathrm{df}=2$ ). Box $\mathrm{M}$ test could not be computed because there were fewer than 2 nonsingular cell covariance matrices

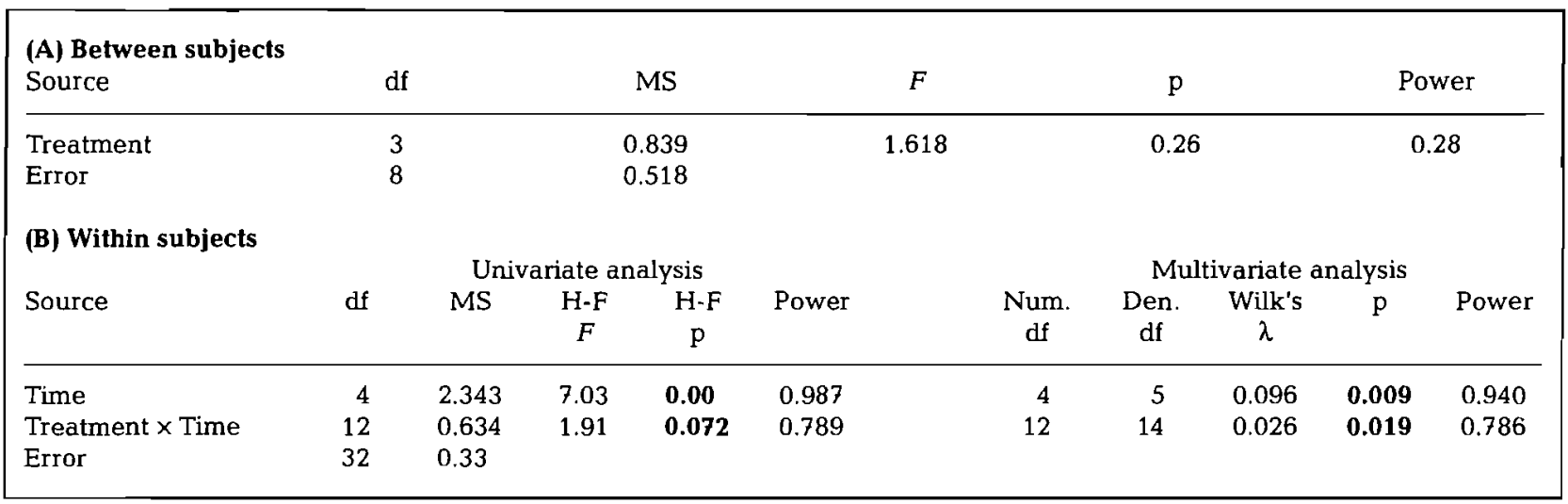

the pattern was different. While we found no significant overall impacts of sea urchin grazing on turtlegrass biomass (Table 3, between-subject effects), grazing did have a highly significant impact on how aboveground turtlegrass biomass changed in summer (Table 3, within-subject effects: time $\times$ treatment interaction [univariate only]). In the first month of the experiment, aboveground biomass increased somewhat in the control treatment, while it decreased dramatically in each grazing treatment (Fig. 3a). Even though sea urchin densities were identical in all grazing treatments during the first month of the experiment, pairwise contrasts showed that only 2 of the 3 grazing treatments had significantly lower biomass than the ungrazed control treatment. ln the second month of the experiment, no. significant differences were detected among treatments as turtlegrass bio- mass had increased in all of the grazing treatments. Biomass changed little in the ungrazed treatment during this same period of time. In Month 3, pairwise contrasts showed that the treatment grazed for $1 \mathrm{mo}$ had significantly higher turtlegrass biomass than the other treatments (Fig. 3a). When grazing pressure was relaxed in summer, aboveground biomass increased rapidly in each of the grazing treatments (Fig. 3a). In the treatment grazed for 1 mo (i.e., the treatment where sea urchins were removed in July), biomass was double that observed in the ungrazed control at the end of the experiment. In the treatment where sea urchins remained for 2 mo (i.e., the treatment where sea urchins were removed in August), aboveground biomass decreased during the first month as well (by some $40 \%$ ) then rapidly increased to levels that were statistically indistinguishable from those of the control 
Table 3. Repeated measures ANOVA of summer grazing effects by Lytechinus variegatus on aboveground biomass in Big Pine Key, Florida. Bold indicates statistically significant differences among treatments. Differences were considered to be highly significant when $\mathrm{p}<0.05$ and marginally significant when $\mathrm{p}<0.10$. Note: data do show homogeneity of treatment variances (Sphericity test, $\mathrm{p}=0.762 ; \mathrm{df}=2$ ). Box $\mathrm{M}$ test could not be computed because there were fewer than 2 nonsingular cell covariance matrices

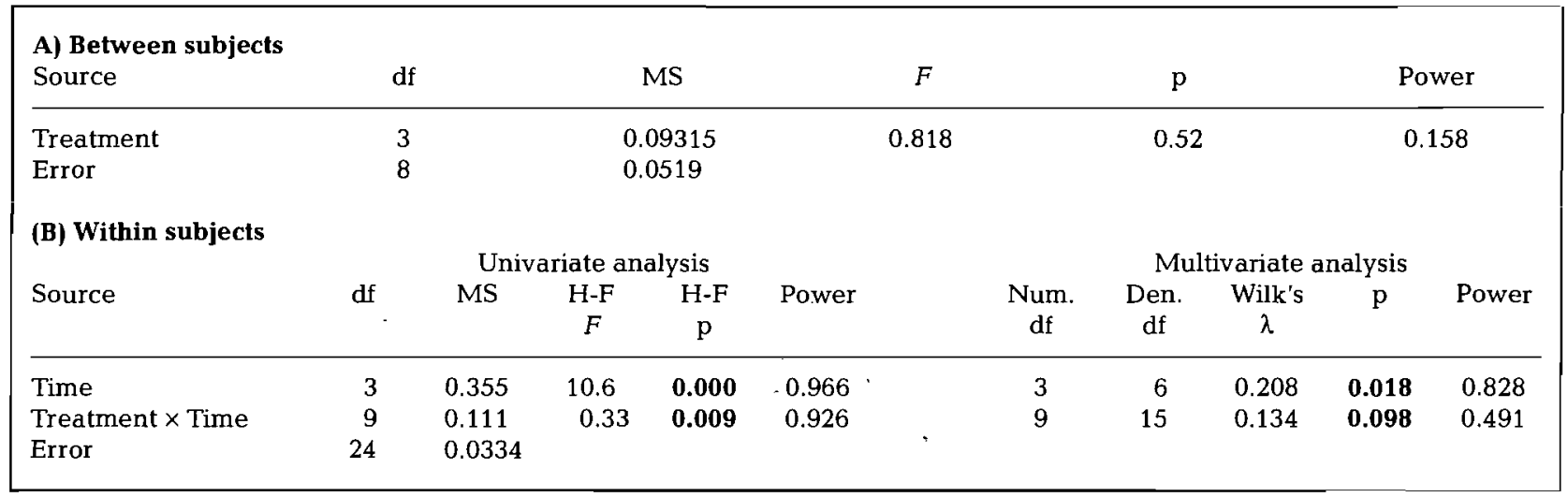

Table 4: Repeated measures ANOVA of summer grazing effects by Lytechinus variegatus on belowground biomass in Big Pine Key, Florida. Bold indicates statistically significant differences among treatments. Differences were considered to be highly significant when $\mathrm{p}<0.05$ and marginally significant when $\mathrm{p}<0.10$. Note: data do not show homogeneity of treatment variances (Sphericity test, $\mathrm{p}=0.010 ; \mathrm{df}=2$ ). Huynh-Feldt corrected degrees of freedom, $F$ values and probabilities $(P H-F)$ are given for the univariate within subjects analysis $(\mathrm{H}-\mathrm{F} \varepsilon=0.7)$. Box $M$ test could not be computed because there were fewer than 2 nonsingular cell covariance matrices

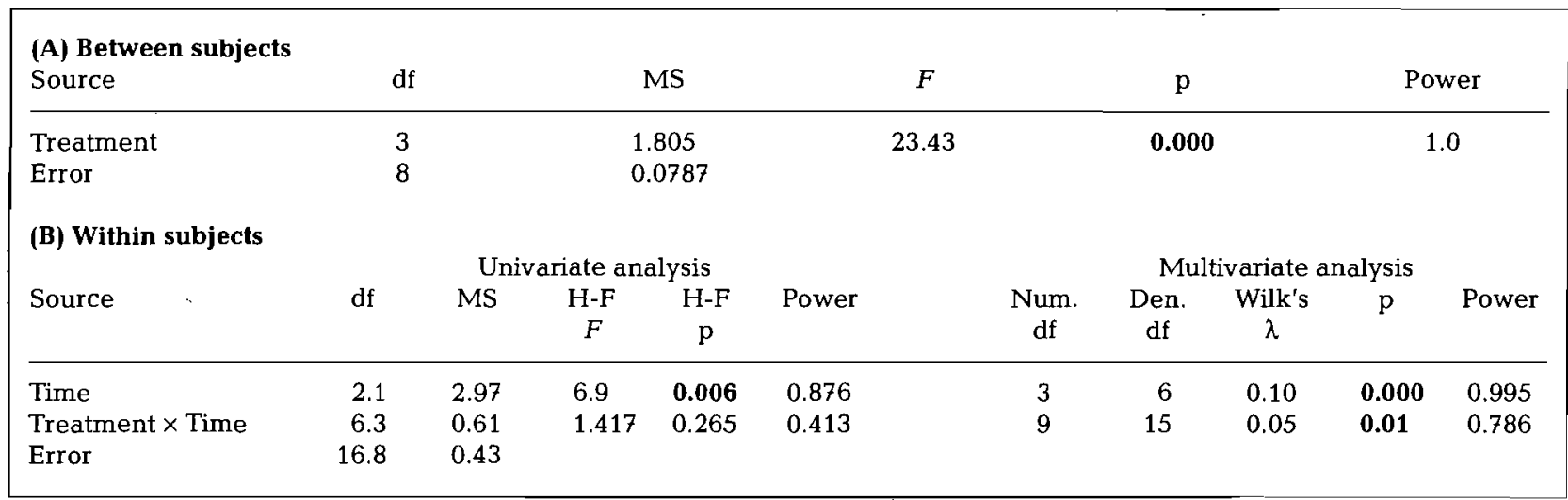

treatment. In the treatment where grazers remained for $3 \mathrm{mo}$, the lowest aboveground biomass was observed in July (some $37 \%$ of initial values), after which there was a substantial recovery (some $66 \%$ of original biomass).

This pattern of initial losses was followed by rapid accumulation of 'new' biomass, to the point that we could not detect statistically significant differences among treatments. This suggests that grazing stimulated large increases in aboveground NAPP in the summer experiment. Grazing had a highly significant impact on belowground biomass in summer (Table 4, between-subject effects). Belowground biomass in the control treatment changed little during the experi- ment, whereas belowground biomass oscillated widely in the grazing treatments. Pairwise contrasts of treatment effects found a single significant difference to exist after 1 mo of grazing (i.e., between the cages grazed for 2 mo and all other treatments) (Fig. 3b). In the second month, cages grazed for 1 and 3 mo were significantly different from either those grazed for 2 mo or controls. In the third month of the experiment, significant differences among treatments grazed for 1 and 2 mo were found. The higher levels of biomass in 2 of the 3 grazing treatments than in the ungrazed control at the end of the experiment again point towards increased levels of primary production as a result of grazing (Fig. 3b). 

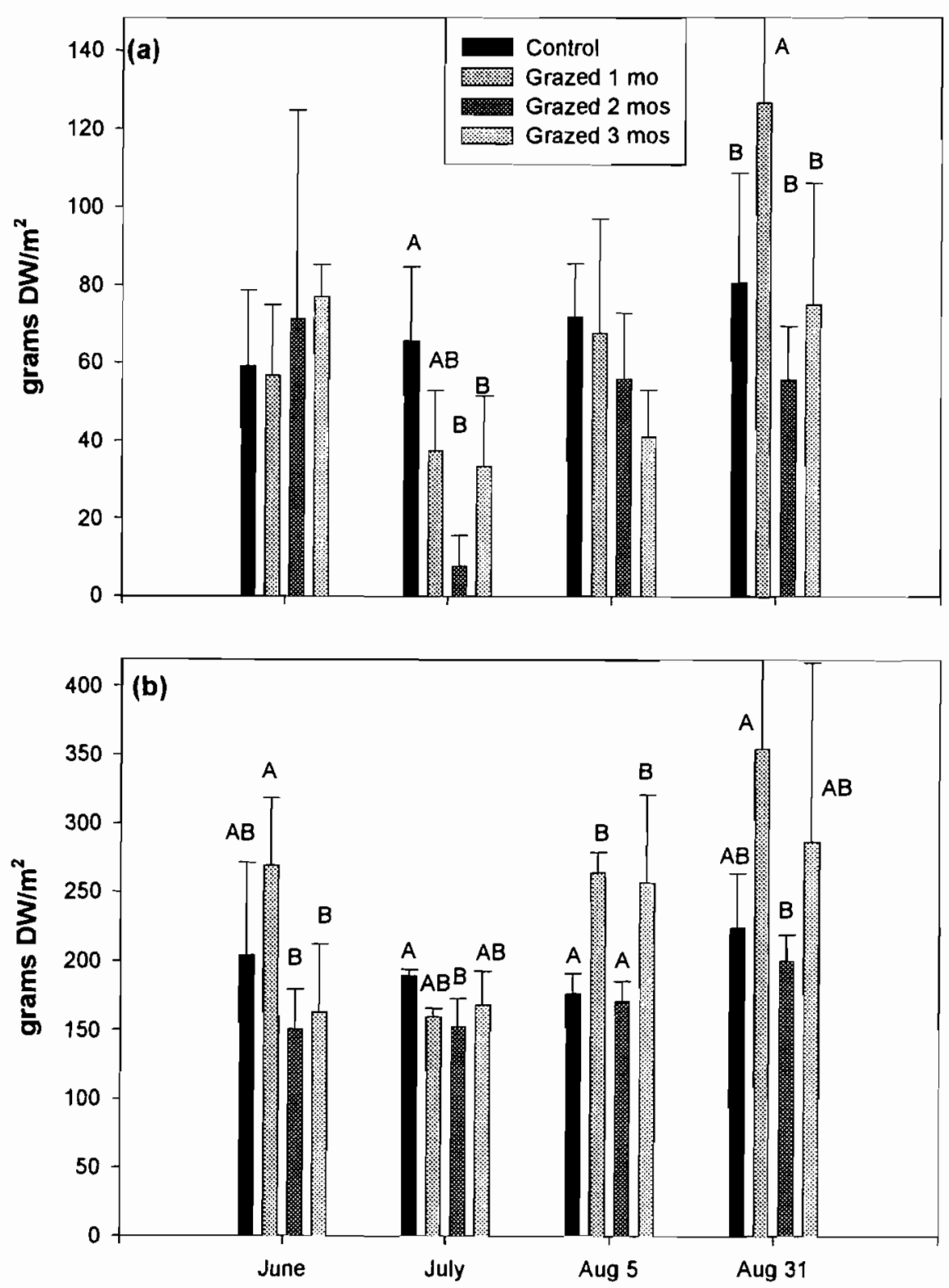

Fig. 3. (a) Aboveground and (b) belowground biomass in cages grazed by sea urchins for either 1, 2 or 3 mo during summer in Big Pine Key (mean $+1 \mathrm{SE}, \mathrm{n}=3$ ). Letters indicate treatments that were significantly different

\section{Grazing in Hawk Channe]}

Initial comparisons of the selected parameters found no statistically significant differences among treatments $(p>0.1)$. This indicates that our study area was relatively homogeneous with regard to the selected response measures of turtlegrass growth and abundance (Figs. 4 to 7 ). Further analysis showed that grazing marginally affected only 1 of these parameters (leaf length) in Hawk Channel (Table 5). Pairwise comparisons found that leaves were significantly longer in the cages with sea urchins at densities of 4 ind. $\mathrm{m}^{-2}$ than in either of the other 2 treatments. These results suggest that grazing plays only a small role in controlling the distribution and abundance of turtlegrass in Hawk Channel. However, unlike our experiments in Big Pine Key, the statistical power of this experiment in Hawk Channel to detect significant differences among treatments was low for each response variable (Table 5). As a result, the probability of making a Type II error (i.e., not rejecting a false null hypothesis) is very high. 

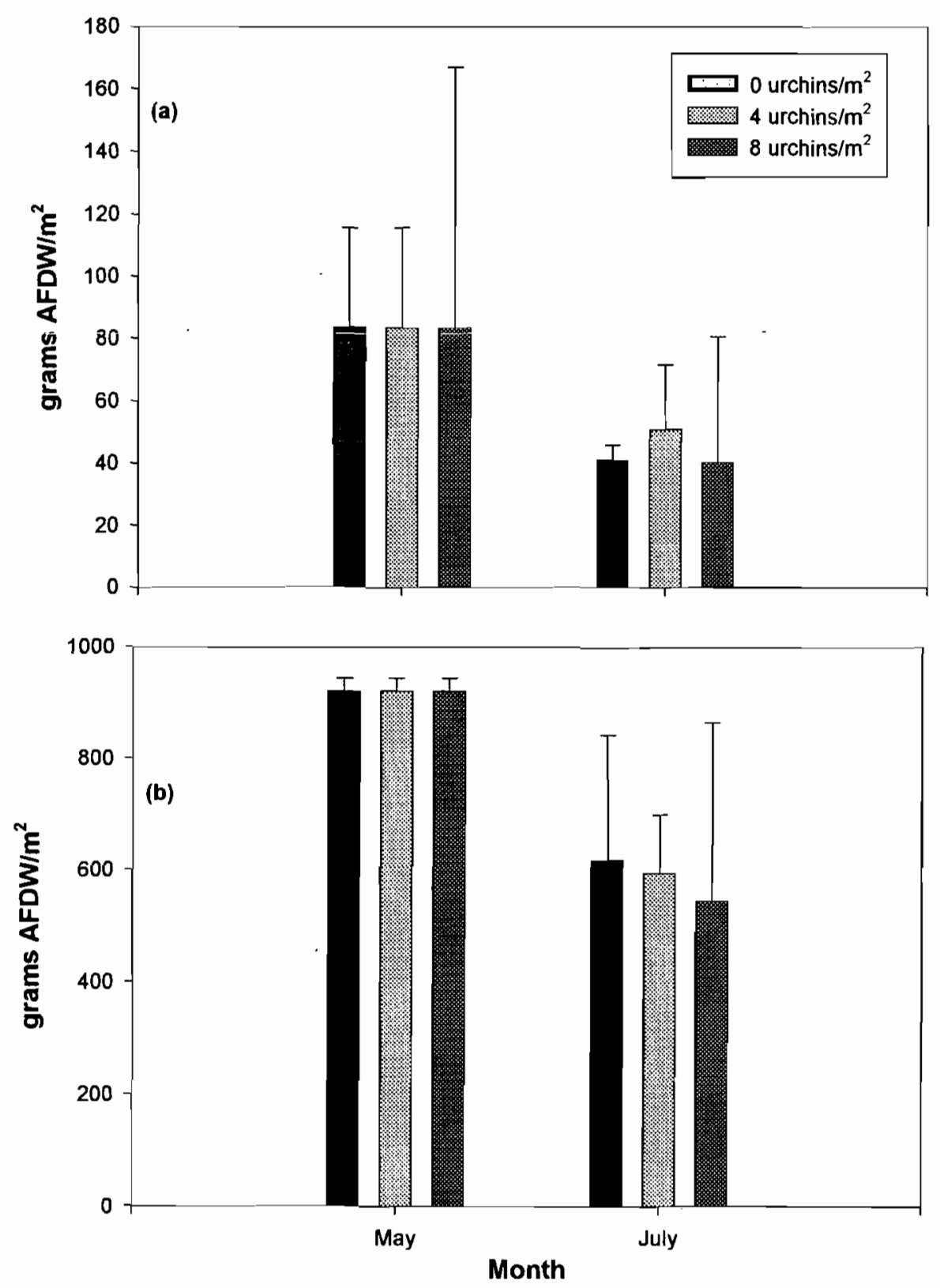

Fig. 4. (a) Aboveground and (b) belowground biomass in cages grazed by sea urchins in Hawk Channel (mean +1 SE, $\mathrm{n}=7$ )

\section{Surveys of sea urchin densities in northern and middle Florida Keys}

Sea urchin densities were similar at all study sites. Initial densities of Lytechinus variegatus ranged from 0 to 7 ind. $m^{-2}(n=49)$ in the Hawk Channel vicinity and from 0 to 6 ind. $\mathrm{m}^{-2}(\mathrm{n}=20)$ in the Big Pine Key area. Of the 3 sites selected to record densities, sea urchins were not found north or west of Big Pine Key but occurred along the southern shoreline of Big Pine Key at an average density of 3.9 ind. $\mathrm{m}^{-2}$. Sea urchins were found commonly throughout Hawk Channel. Of the 22 locations sampled, L. variegatus was present at 19. Average densities at the selected sites along the $80 \mathrm{~km}$ segment of Hawk Channel surveyed ranged from 0 to 3.33 ind. $\mathrm{m}^{-2}$. Longer-term monitoring of sea urchin density showed a steady decline between April 1995 and September 1996 at our study site in Hawk Channel (Fig. 8). Over the $1.5 \mathrm{yr}$ period, average sea urchin densities dropped from 1.7 to 0.7 ind. $\mathrm{m}^{-2}$. 

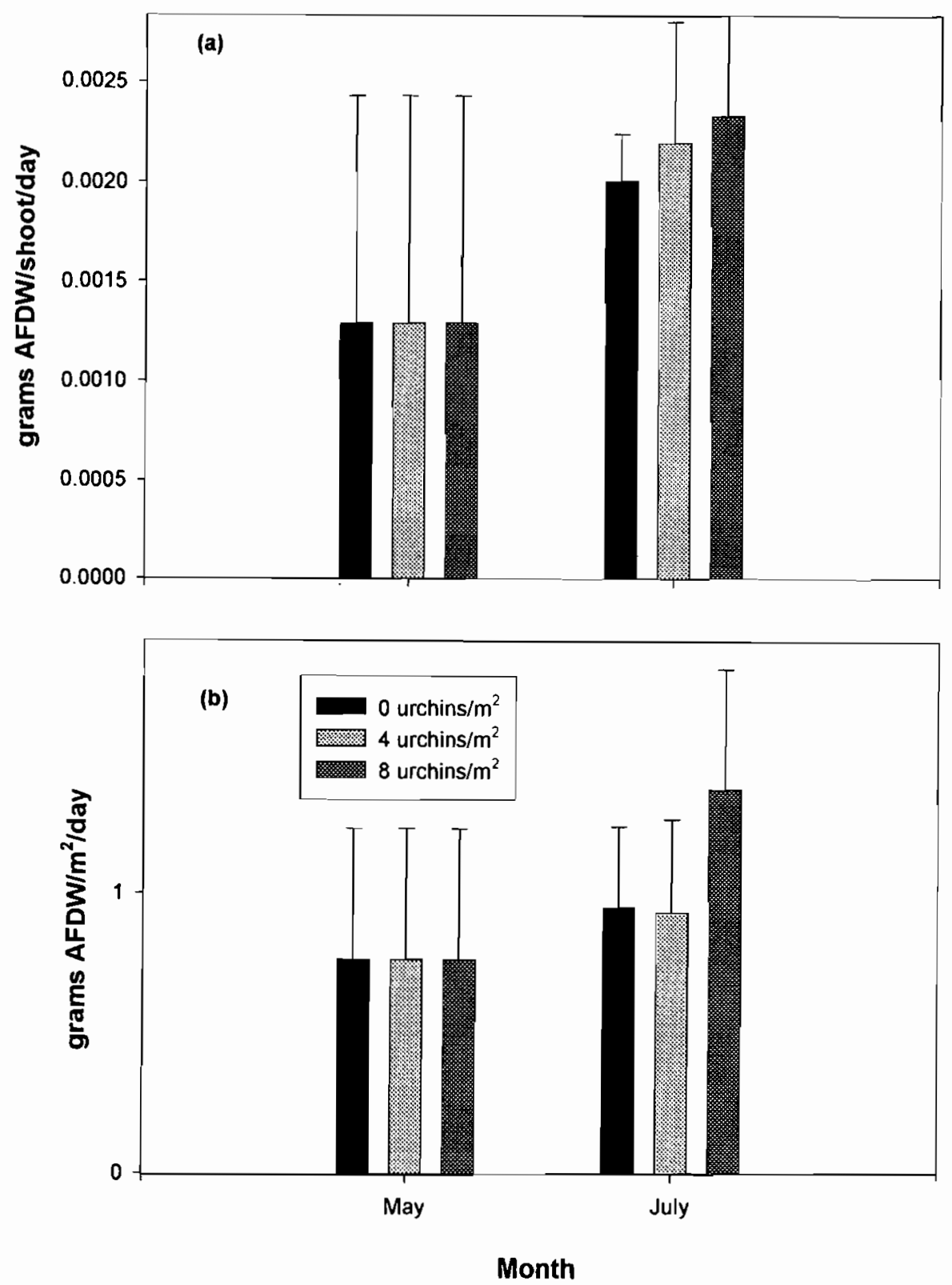

Fig. 5. (a) Short-shoot-specific production and (b) net aboveground primary production in cages grazed by sea urchins in Hawk Channel (mean $+1 \mathrm{SE}, \mathrm{n}=7)$

\section{DISCUSSION}

We found that sea urchin grazing can control seasonal changes in turtlegrass abundance in some areas of the Florida Keys. At Big Pine Key, grazing had a significant, negative impact on turtlegrass biomass throughout the spring. Grazing duration had little effect on seagrass abundance, as short grazing bouts were as effective as longer periods of grazing in reducing aboveground biomass. The lack of biomass accu- mulation, once grazing pressure was relaxed, indicates that seagrass growth was minimal during spring. Once the growing season began, turtlegrass regrew and reached levels exceeding those in ungrazed cages by mid-summer. This is similar to what we found in the northern Gulf of Mexico (Valentine \& Heck 1991). We also found that sea urchin grazing controlled how belowground biomass changed in spring at Big Pine Key but the manner in which grazing affected these changes remains unclear. 

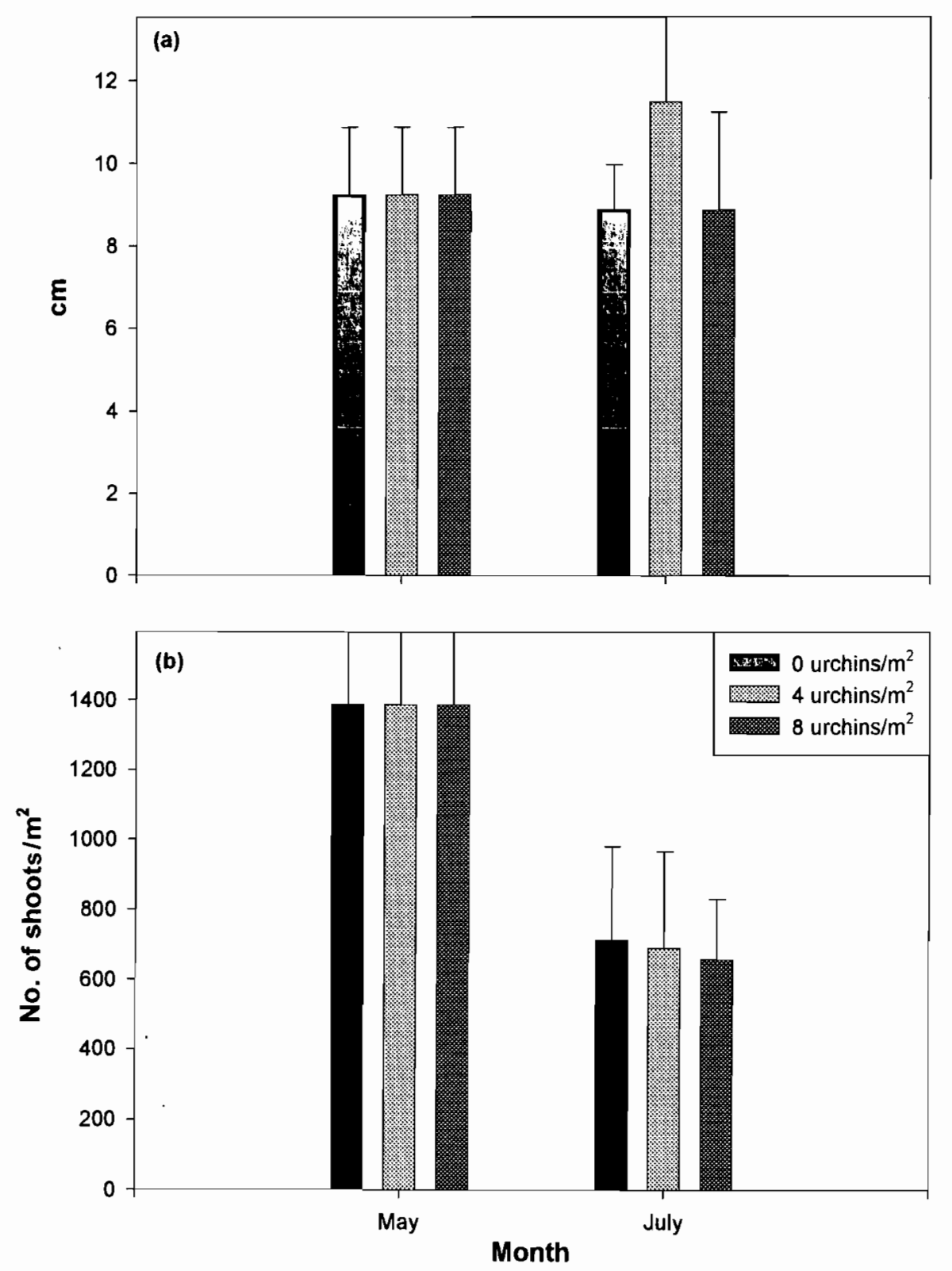

Fig. 6. (a) Leaf length and (b) short shoot density in cages grazed by sea urchins in Hawk Channel (mean $+1 \mathrm{SE}, \mathrm{n}=7)$

In summer, however, when seagrass growth is at its zenith (Zieman \& Zieman 1989), the impacts of grazing on turtlegrass biomass were far less uniform. The rapid regrowth of aboveground seagrass biomass, which in some cases reached higher levels than observed in the ungrazed control treatment, indicates that grazing must have stimulated seagrass production during the summer months. While we did not directly measure NAPP at Big Pine Key, it is possible to estimate the total amount of production that occurred in our treatments using a simple mass balance equation (NAPP $=$ the change in biomass [i.e., biomass ${ }_{t+1}-$ biomass $\left._{t 0}\right]+$ bio- mass consumed by sea urchins + leaf loss due to senescence, over an interval of time). We cannot use this formula to estimate aboveground production, as we have no direct estimates of consumption by grazers or leaf loss. We can, however, use this formula to estimate net belowground primary production if we assume that the sea urchins do not consume belowground tissue and no tissue was differentially lost among treatments. Since sea urchins cannot reach belowground biomass and there are no transport processes that can carry the belowground material away from our cages, we believe these are reasonable assumptions. Using this 


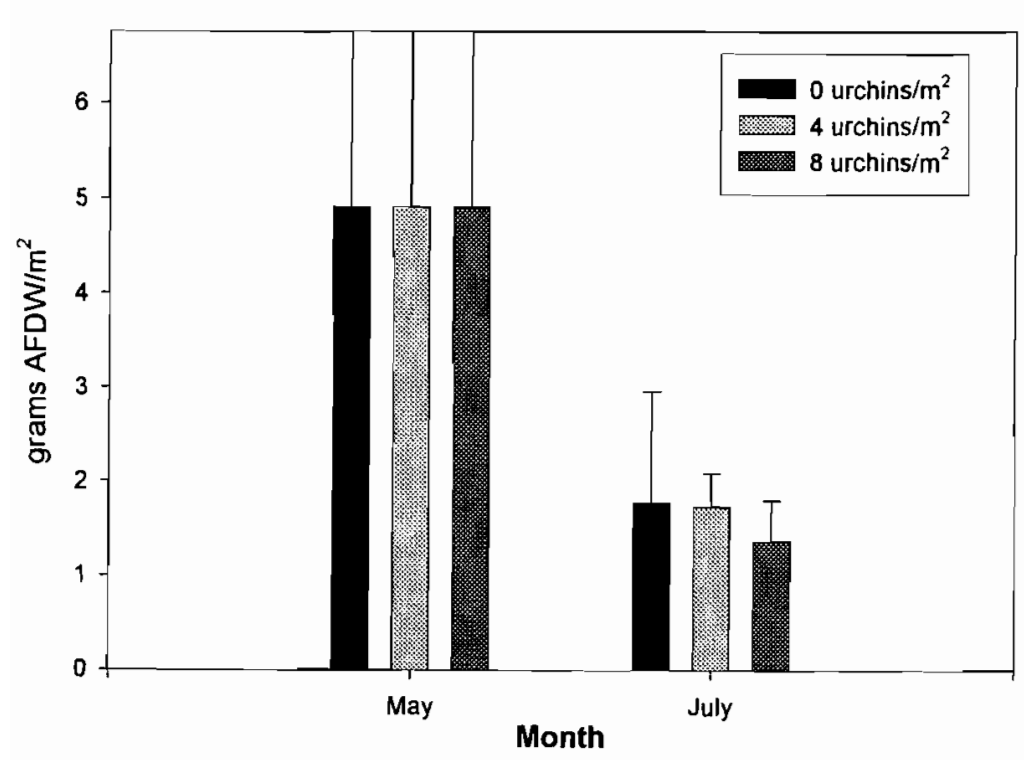

Fig. 7. Epibiont biomass in cages grazed by sea urchins in Hawk Channel $($ mean $+1 \mathrm{SE}, \mathrm{n}=7)$

formula, we estimate that net belowground primary production (from June through August) in our experiment was $0.198,0.8483,1.2963$, and $0.4759 \mathrm{~g}$ dry wt $\mathrm{m}^{-2}$ in treatments with no sea urchins and those with sea urchins enclosed for 1,2 and 3 mo, respectively. We estimate that belowground primary production in the grazing treatment was more than double that of the ungrazed control treatment during summer. Since rhizome growth occurs at rhizome apices, and new shoots are produced almost always at rhizome apices (Tomlinson \& Vargo 1966, Tomlinson 1974), it is likely that sea urchin grazing also led to increased aboveground production in our summer experiment. Based on these observations, and our earlier work showing that sea urchin grazing can stimulate aboveground seagrass production (Valentine et al. 1997), we conclude that determining the importance of seagrass herbivory to nearshore food webs based solely on relative reductions in seagrass biomass in grazed versus ungrazed cages is inappropriate, as it substantially underestimates the amount of plant consumption by marine herbivores.

We anticipated that sea urchins would have highly significant negative impacts on turtlegrass biomass at the Hawk Channel study site, even though the densities used in this experiment were lower than those in the Big Pine Key experiments. We anticipated this, in part, because the increased depth of our study site in Hawk Channel would have much lower light levels than the shallow water at the Big Pine Key study site. However, we found no evidence that the lower densities significantly influenced turtlegrass growth or abundance in Hawk Channel. The reasons for this are unclear, but one obvious possibility is that the lower densities of sea urchins used in this experiment were below the threshold necessary to significantly affect either seagrass growth or the accumulation of biomass. However, experiments conducted in the shallow waters of St. Joseph Bay showed that only slightly higher sea urchin densities (i.e., 10 ind. $\mathrm{m}^{-2}$ ),

Table 5. Summary of ANOVAs describing the grazing impacts on turtlegrass within our cages in Hawk Channel, Florida, during July. Degrees of freedom for all tests are 2 and 12 . Bold indicates statistically significant differences among treatments. Differences were considered to be highly significant when $p<0.05$ and marginally significant when $p<0.10$

\begin{tabular}{|c|c|c|c|c|c|}
\hline Plant characteristic & Source & SS & $F$ & $\mathrm{p}$ & Power \\
\hline Aboveground biomass & $\begin{array}{l}\text { Model } \\
\text { Error }\end{array}$ & $\begin{array}{l}349.02 \\
3983.3\end{array}$ & 0.53 & 0.6 & 0.12 \\
\hline Belowground biomass & $\begin{array}{l}\text { Model } \\
\text { Error }\end{array}$ & $\begin{array}{l}13809.66 \\
649700.4\end{array}$ & 0.13 & 0.88 & 0.07 \\
\hline Shoot density & $\begin{array}{l}\text { Model } \\
\text { Error }\end{array}$ & $\begin{array}{r}7614.5 \\
712959.8\end{array}$ & 0.06 & 0.94 & 0.06 \\
\hline Shoot-specific NAPP & $\begin{array}{l}\text { Model } \\
\text { Error }\end{array}$ & $\begin{array}{l}0.0000001 \\
0.0000002\end{array}$ & 0.6 & 0.56 & 0.13 \\
\hline Areal NAPP & $\begin{array}{l}\text { Model } \\
\text { Error }\end{array}$ & $\begin{array}{r}0.632 \\
1.52\end{array}$ & 0.12 & 0.88 & 0.40 \\
\hline Leaf length & $\begin{array}{l}\text { Model } \\
\text { Error }\end{array}$ & $\begin{array}{l}22.54 \\
43.72\end{array}$ & 3.1 & 0.08 & 0.49 \\
\hline Epibiont biomass & $\begin{array}{l}\text { Model } \\
\text { Error }\end{array}$ & $\begin{array}{l}0.49 \\
6.73\end{array}$ & 0.44 & 0.65 & 0.11 \\
\hline
\end{tabular}




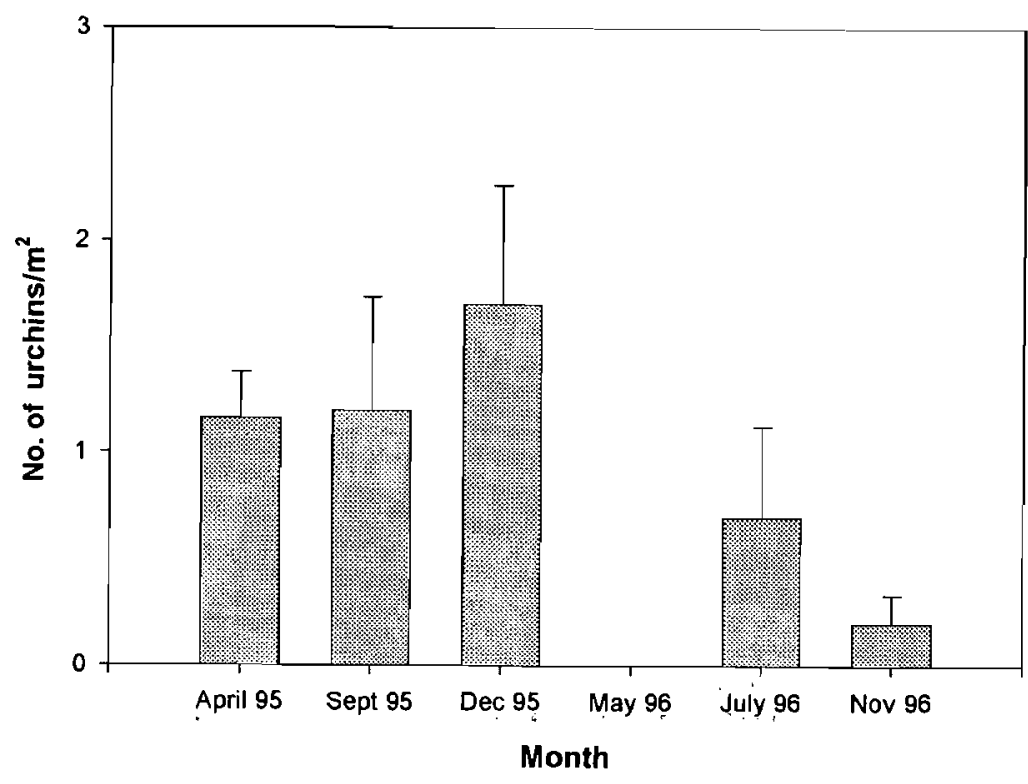

Fig. 8. Sea urchin density in Hawk Channel (mean $+1 S E, n=10)$ this grazing covered at least $10 \mathrm{~km}^{2}$ and extended across a $2 \mathrm{~km}$ southwardmigrating front (Rose et al. 2000).

In this study, the differences in grazer impacts on turtlegrass growth and abundance, in a well-lit shallow water habitat and deeper-water habitat with less light, suggest that there is a critical need not only to repeat experiments in environments with differing physical conditions, but also to develop a more complete understanding of the mechanisms by which seagrasses can compensate for losses of tissues to marine herbivores under varying environmental conditions. Only then will we be able to accurately estimate the amount of energy entering nearshore food webs via the grazing pathway. To date, there have been no field experiments that have simultaneously considered the multiple controlling factors that determine just how much energy actually flows from seagrasses to herbivores. had a major impact on seagrass growth (Valentine et al. 1997). It is also possible that modest increases in production observed in July, albeit not statistically significantly higher, were sufficient to allow turtlegrass to persist in our experiments. Alternatively, the statistical power of the Hawk Channel experiment was extraordinarily low and we may have simply made a Type II error. This low power was surprising, as treatment replication and the densities used were similar to our previous studies (Valentine \& Heck 1991, Heck \& Valentine 1995, Valentine et al. 1997, this study at Big Pine Key).

Overall, sea urchin densities at our study sites were much lower than in St. Joseph Bay (Valentine \& Heck 1991). These new experiments suggest that Lytechinus variegatus is unlikely to have the same major effects on turtlegrass abundance in the Florida Keys that we reported from the northern Gulf of Mexico (but see Moore et al. 1963, Bach 1979, Maciá \& Lirman 1999]. However, sea urchins may produce substantial effects on other species of seagrass in south Florida. In 1997, local fishermen reported that high numbers of sea urchins were found in lobster traps in Florida Bay (Rose et al. 2000). Divers discovered that aggregations (with localized densities exceeding 300 ind. $\mathrm{m}^{-2}$ ) of $L$. variegatus were grazing heavily on manatee grass Syringodium filiforme throughout the area (Rose et al. 2000). The result was the conversion of a lush seagrass meadow into a heterogeneous landscape, composed of barren unvegetated sand flats, and a combination of heavily grazed and ungrazed patches of $S$. filiforme. Aerial photography and ground-truthing suggest that
Acknowledgements. This work was supported by the Biological Oceanography Program of the National Science Foundation (Grant No. OCE-9102217), the National Science Foundation (Alabama) Experimental Program to Stimulate Competitive Research (R11-8996152), the DISPro program, a joint program between the Environmental Protection Agency's EMAP program and the National Park Service (Grant No. 2350-7-0882), and the National Undersea Research Center (UNCW \#9537). Special thanks are extended to the Dauphin lsland Sea Lab for logistical support, now Drs B. Peterson and P. Bologna, Mss J. Zande and K. Canter for help in the field, Ms S. Sklenar for data processing, and Ms Carolyn Wood for word processing and to Captains Fuzzy O'Leary and Dan Aspenleiter for diving and boat support and an excellent sense of humor. Additionally, the authors would like to thank Drs R. Aronson, Judson Kenworthy and Just Cebriàn, Mssr Mike Dardeau, Geremea Fioravanti and 3 anonymous reviewers for constructive criticisms of this work. This is MESC Contribution No. 304.

\section{LITERATURE CITED}

Bach SD (1979) Standing crop, growth and production of calcareous siphonales (Chlorophyta) in a South Florida lagoon. Bull Mar Sci 29:191-201

Bjorndal KA (1980) Nutrition and grazing behavior of the green turtle Chelonia mydas. Mar Biol 56:147-154

Camp DK, Cobb SP, van Breedfield JF (1973) Overgrazing of seagrasses by a regular urchin, Lytechinus variegatus. BioScience 23:37-38

Cebrián J, Duarte CM (1998) Patterns in leaf herbivory on seagrasses: the importance of the specific leaf growthrate. Aquat Bot 60:67-82

Cebrián J, Duarte CM, Marbà $N$, Enriquez $S$, Gallegos $M$, Olesen B (1996) Herbivory on Posidonia oceanica: magni- 
tude and variability in the Spanish Mediterranean. Mar Ecol Prog Ser 130:147-155

Charman K (1979) Feeding ecology and energetics of the dark-bellied brent goose (Branta bernicla) in Essex and Kent. In: Jefferies RL, Davys AJ (eds) Ecological processes in coastal environments. Blackwell Scientific Publications, Oxford, $\mathrm{p}$ 451-465

Demot WR, Kerfoot WC (1982) Competition among cladocerans: nature of the interaction between Bosmina and Daphnia. Ecology 63:1949-1966

Duarte CM (1990) Seagrass nutrient content. Mar Ecol Prog Ser 67:201-207

Engstrom NA (1982) Immigration as a factor in maintaining populations of the sea urchin Lytechinus variegatus (Echinodermata: Echinoidea) in sea grass beds on the southwest coast of Puerto Rico. Stud Neotropic Fauna Environ 17:51-60

FencheI T (1970) Studies on the decomposition of organic detritus derived from the turtlegrass Thalassia testudinum. Limnol Oceanogr 15:14-20

Fenchel T (1977) Aspects of the decomposition of seagrasses. McRoy CP, Helferich C (eds) Seagrass ecosystems: a scientific perspective. Marcel Dekker, Inc, New York, p 123-145

Gaines SD, Lubchenco J (1982) A unified approach to marine plant-herbivore interactions. II. Biogeography. Annu Rev Ecol Syst 13:111-138

Greenway $M$ (1976) The grazing of Thalassia testudinum in Kingston Harbor, Jamaica. Aquat Bot 2:117-126

Harrison PG, Mann KH (1975) Detritus formation from eelgrass (Zostera marina L.): the relative effects of fragmentation, leaching, and decay. Limnol Oceanogr 20:924-934

Hatcher A (1994) Nitrogen and phosphorus turnover in some benthic marine invertebrates: implications for the use of $\mathrm{C}: \mathrm{N}$ ratios to assess food quality. Mar Biol 121:161-166

Hay ME, Steinberg PD (1992) The chemical ecology of plantherbivore interactions in marine versus terrestrial communities. In: Rosenthal GA, Berenbaum MR (eds) Herbivores: their interactions with secondary plant metabolites. Academic Press, San Diego, p 372-413

Heck KL Jr, Valentine JF (1995) Sea urchin herbivory: evidence for long-lasting effects in subtropical seagrass meadows. J Exp Mar Biol Ecol 189:205-217

Heinsohn GE, Birch WR (1972) Foods and feeding habits of the dugong, Dugong dugong, (Erxleben), in northern Queensland, Australia. Mammalia 36:414-422

Jacobs RPW, den Hartog MC, Braster BF, Carriere FC (1981) Grazing of the seagrass Zostera noltii by birds at Tertschelling (Dutch Wadden Sea). Aquat Bot 10:241-259

Kenworthy WJ, Schwarzchild AC (1998) Vertical growth and short-shoot demography of Syringodium filiforme in outer Florida Bay, USA. Mar Ecol Prog Ser 173:25-37

Kikuchi $T(1980)$ Faunal relationships in temperate seagrass beds. In: Phillips RC (ed) Handbook of seagrass biology: an ecosystem perspective. Garland STPM Press, New York, p 153-172

Kikuchi T, Pérès JM (1977) Consumer ecology of seagrass beds. In: McRoy CP, Helfferich C (eds) Seagrass ecosystems: a scientific perspective. Marcel Dekker, Inc, New York, p 147-194

Kiorbøe T (1980) Distribution and production of submerged macrophytes in Tipper Grund (Ringkøbing Fjord, Denmark), and the impact on grazing. J Appl Ecol 17:675-687

Kirkman $H_{r}$ Reid DD (1979) A study of the role of seagrass Posidonia australis in the carbon budget of an estuary. Aquat Bot 7:173-183

Kumpp DW, van der Walk A (1984) Nutritional quality of sea- grasses (Posidonia australis and Heterozostera tasmanica): comparison between species and stages of decomposition. Mar Biol Lett 5:67-83

Klumpp DW, Howard RK, Pollard DA (1989) Trophodynamics and nutritional ecology of seagrass communities. In: Larkum AWD, McComb AJ, Shepherd SA (eds) Biology of seagrasses. Elsevier, New York, p 394-457

Klumpp DW, Salita-Espinosa JT, Fortes MT (1993) Feeding ecology and trophic role of sea urchins in a tropical seagrass community. Aquat Bot 45:205-229

Lawrence JM (1975) On the relationship between marine plants and sea urchins. Oceanogr Mar Biol Annu Rev 13: $213-286$

Lewis SM (1985) Herbivory on coral reefs: alga susceptible to herbivorous fishes. Oecologia 65:370-375

Lipkin Y (1975) Quantitative aspects of seagrass communities, particularly of those dominated by Halophila stipulacea, in Sinai (Northern Red Sea). Aquat Bot 7:119-128

Lobel PS, Ogden J (1981) Foraging by the herbivorous parrotfish Sparisoma radians. Mar Biol 64:173-183

Lowe EF, Lawrence JM (1976) Absorption efficiencies of Lytechinus variegatus (Lamarck) (Echinodermata: Echinoidea) for selected marine plants. J Exp Mar Biol Ecol 21: $223-234$

Lubchenco J, Gaines SD (1981) A unified approach to marine plant-herbivore interactions. I. Populations and communities. Annu Rev Ecol Syst 12:405-437

Lynch M, Shapiro J (1981) Predation, enrichment, and phytoplankton community structure. Limnol Oceanogr 29: 243-252

Maciá S, Lirman D (1999) Destruction of Florida Bay seagrasses by a grazing front of sea urchins. Bull Mar Sci 65: 593-601

Mallin MA, Paerl HW (1994) Planktonic trophic transfer in an estuary: seasonal, diel, and community structure effects. Ecology 75:2168-2184

McCauley E, Briand F (1979) Zooplankton grazing and phytoplankton species richness: field tests of the predation hypothesis. Limnol Oceanogr 24:243-253

Moore HB, Jute T, Bauer JC (1963) The biology of Lytechinus variegatus. Bull Mar Sci Gulf Caribb 13:23-53

Nienhuis PH, Groenendijk PH (1986) Consumption of eelgrass (Zostera marina) by birds and invertebrates: an annual budget. Mar Ecol Prog Ser 29:29-35

Nienhuis PH, Van lerland ET (1978) Consumption of eelgrass, Zostera marina, by birds and invertebrates during the growing season in Lake Grevekingen (SW Netherlands). Neth J Sea Res 12:180-194

Porter KG (1973) Selective grazing and differential digestion by zooplankton. Nature 224:179-180

Porter KG (1977) The plant-animal interface in freshwater ecosystems. Am Nat 65:159-170

Randall JE (1965) Grazing effect on sea grasses by herbivorous reef fishes in the West Indies. Ecology 46:255-260

Rice D (1982) The detritus nitrogen problem: new observations and perspectives from organic geochemistry. Mar Ecol Prog Ser 9:153-162

Roessler MA, Tabb DC (1974) Studies of affects of thermal pollution in Biscayne Bay, Florida. Rep No. 660/2-74-014. EPA, Washington, DC

Roessler MA, Beardsley GL, Rehrer R, Garcia J (1975) Effects of thermal effluents on the fishes and benthic invertebrates of Biscayne Bay-Card Sound, Florida. Univ Miami Tech Rep UM-RSMAS no. 75027

Rose CD, Sharp WC, Kenworthy WJ, Hunt JH, Lyons WG, Prager EJ, Valentine JF, Hall MO, Whitfield P, Fourqurean JW (2000) Overgrazing of a large seagrass bed by the sea 
urchin Lytechinus variegatus in Outer Florida Bay. Mar Ecol Prog Ser 190:211-222

Russell-Hunter WD (1970) Aquatic productivity: an introduction to some basic aspects of biological oceanography and limnology. Macmillan Co, London

Thayer GW, Engel DW, La Croix MW (1977) Seasonal distribution and changes in the nutritive quality of living and detrital fractions of Zostera marina L. J Exp Mar Biol Ecol 30:109-127

Thayer GW, Bjorndal KA, Ogden JC, Williams SL, Zieman JC (1984) Role of larger herbivores in seagrass communities. Estuaries 7:351-376

Thorhaug A, Roessler MA (1977) Seagrass community dynamics in a subtropical estuarine lagoon. Aquaculture 12:253-277

Tomlinson PB (1974) Vegetative morphology and meristem dependence - the foundation of productivity in seagrasses. Aquaculture 4:107-130

Tomlinson PB, Vargo GA (1966) On the morphology and anatomy of turtle grass, Thalassia testudinum (Hydrocharitaceae). I. Vegetative morphology. Bull Mar Sci 16: $748-761$

Valentine JF, Heck KL Jr (1991) The role of sea urchin grazing in regulating subtropical seagrass meadows: evidence from field manipulations in the northern Gulf of Mexico. J Exp Mar Biol Ecol 154:215-230

Editorial responsibility: John Lawrence (Contributing Editor), Tampa, Florida, USA
Valentine JF, Heck KL Jr (1999) Seagrass herbivory: evidence for the continued grazing of marine grasses. Mar Ecol Prog Ser 176:291-302

Valentine JF, Heck KL Jr, Busby J, Webb D (1997) Experimental evidence that herbivory can increase shoot density in a subtropical turtlegrass (Thalassia testudinum) meadow. Oecologia 112:193-200

Vanni MJ (1987a) Effects of nutrients and zooplankton size on the structure of a phytoplankton community. Ecology 68 : $624-635$

Vanni MJ (1987b) Effects of nutrients and zooplankton size on the structure of a phytoplankton community Ecology 68 : $624-635$

von Ende CN (1993) Repeated-measures analysis: growth and other time-dependent measures. In: Scheiner SM, Gurevitch $\mathbf{J}$ (eds) Design and analysis of ecological experiments. Chapman and Hall, London, p 113-137

Williams SL (1990) Experimental studies of Caribbean seagrass bed development. Ecol Monogr 60:449-469

Zieman JC (1975) Quantitative and dynamic aspects of the ecology of turtle grass, Thalassia testudinum. In: Cronin LE (ed) Estuarine research. Academic Press, New York, p 541-562

Zieman JC, Zieman RT (1989) The ecology of the seagrass meadows of the west coast of Florida: a community profile. US Fishwildl Serv Biol Rep 85(725)

Submitted: January 14, 1999; Accepted: November 18, 1999 Proofs received from author(s): June 23, 2000 